International Journal of Instruction e-ISSN: 1308-1470 • www.e-iji.net

Article submission code: 20201123125949

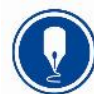

October $2021 \bullet$ Vol.14, No.4

p-ISSN: 1694-609X

pp. $529-548$

Received: 23/11/2020

Revision: 01/04/2021
Accepted: 24/04/2021

OnlineFirst: 11/08/2021

\title{
Students' Critical Thinking Skills in Solving Mathematical Problems; A Systematic Procedure of Grounded Theory Study
}

\section{Marzuki}

School of Postgraduate Studies, Universitas Pendidikan Indonesia \& Mathematics Education Study Program, Indonesia, marzuki@iainlangsa.ac.id \& marzuki@upi.edu

\section{Wahyudin}

Prof., Department of Mathematics Education, Universitas Pendidikan Indonesia, Indonesia,wahyudin.mat@upi.edu

\section{Endang Cahya}

Dr., Department of Mathematics Education, Universitas Pendidikan Indonesia, Indonesia,endangcahya@gmail.com

\section{Dadang Juandi}

Assoc. Prof. Department of Mathematics Education, Universitas Pendidikan Indonesia, Indonesia, dadang.juandi@upi.edu

Critical thinking (CT) is a type of convergent thinking explored when students learn mathematics. This study aims to obtain a comprehensive representation of students' mathematical Critical Thinking (CT) abilities, based on the mathematical ability level. Data were obtained from 35 students using CT skills tests and semistructured in-depth interviews based on the criteria of mathematical ability levels, which was saturated on the 15th interview. The research was qualitatively analyzed using the systematic grounded theory with the help of NVivo 12 plus software, and two coders (kappa $=0.81$ ) to determine the reliability test comprising of 9 categories and 4 themes. The result showed that the higher the mathematical ability level, the more diverse students' thinking patterns in solving problems related to algebraic functions. These findings are expected to help education practitioners in developing students' counseling skills.

Keywords: critical thinking, grounded theory, NVivo 12 plus, mathematical ability level, application of algebraic function derivatives

\section{INTRODUCTION}

Critical Thinking (CT) is the critical analysis and assessment of a problem to shape a decision. It is one of the core competencies of the 21st century (Basri et al., 2019; Changwong et al., 2018; Miller \& Topple, 2020; Sustekova et al., 2019). It is extremely relevant for learners, since it is allows to overcome them difficult challenges as well as

Citation: Marzuki., Wahyudin., Cahya, E., \& Juandi, D. (2021). Students' critical thinking skills in solving mathematical problems; A systematic procedure of grounded theory study. International Journal of Instruction, 14(4), 529-548. https://doi.org/10.29333/iji.2021.14431a 
develop effective communication skills (Ismajli \& Neziri, 2019; Marzuki et al., 2019; Setiyani et al., 2020). In the Indonesian academic context, CT is one of the learning objectives, particularly in the study of mathematics (Darhim et al., 2020; Menteri Pendidikan dan Kebudayaan Republik Indonesia, 2016; Tanudjaya \& Doorman, 2020). Therefore, teaching and learning activities need to aid students in developing this skill.

Furthermore, the teaching of CT skills has been recognized as an aspect to be established (Association of American Colleges and Universities, 2005; Australian Council for Educational Research, 2002; Basri et al., 2019; Sarwanto et al., 2020). However, encouraging students to learn CT skills is a global challenge for educators (Wang \& Woo, 2010), including Indonesia. CT is relevant in any educational setting because it allows individuals should go beyond merely storing more complicated awareness of the information provided to them (Dwyer et al., 2012; Halpern, 2014; Widyatiningtyas et al., 2015). Furthermore, they are also necessary for Social and interpersonal environments where there is a constant need for strong decision-making and problem-solving skills (As'ari et al., 2019; Hage, 2020; Lin et al., 2019). This shows that CT skills are extremely relevant in tackling the 21 st-century challenges.

Consequently, previous studies (Ennis, 1993; Facione, 1992) have defined CT and its various characteristics, such as disposition, critical thinking skills, etc. However, these aspects were independently reviewed, irrespective of the fact that they tend to be integrated and considered as a fundamental characteristic of critical thinking. Subsequently, several studies have examined CT skills by adopting the grounded theory (F. Sadeghi, S. Adel, 2020; Karpouza \& Emvalotis, 2019; Miller \& Topple, 2020; Osman et al., 2016; Store, 2018). However, only a few strategies were considered, despite being unable to offer a comprehensive source of CT skills in accordance with the application of algebraic function derivatives based on the level of mathematical ability, including the handling of students by adopting qualitative research related to systematic grounded theory.

This design has been widely used in educational research, and is much more prescriptive, compared to the previous conceptualization of grounded theory (Glaser, B. G., \& Strauss, 1967). Also, the systematic procedural grounded theory emphasizes the use of data analysis stages including, open, axial, and selective coding, as well as the developing a logical paradigm or a visual image of the appearing theory (Corbin \& Strauss, 1990; Creswell, 2012).

The goal of this research was to obtain a detailed summary of the CT abilities of students based on the level of mathematical skills. The difference between this research and previous ones is the discovery of three new factors, 1) tracking students' CT skills based on the materials concerning the application of algebraic function derivatives, observation, critical thinking skill tests, and in-depth semi-structured interviews using zoom applications, 2) data processing was carried out by using a systematic grounded theory methodology with the help of NVivo 12 plus software, 3) a discussion was conducted with the school's mathematics teacher, to explore the students' initial mathematical ability levels (moderate, high, and very high). Subsequently, the ability levels were analyzed based on the student's report card, tests, and daily tests scores. This 
goal was achieved by adopting a systemic grounded theory methodology (Corbin \& Strauss, 1990; Creswell, 2012), to obtain comprehensive information about the students' CT skills based on their level of mathematical abilities in solving problems related to the application of algebraic function derivatives.

\section{Issues and Aims of the Study}

Based on the introduction above, the problems raised in this study is the categorization of students' critical thinking skills as moderate, high, or very high, in solving mathematical problems within the application of derivative function material, in Senior High School.

\section{METHOD}

\section{Participants}

A total of 35 students were selected as participants for this study, based on the report cards, tests, and daily tests scores. Students at this school use the Semester Credit System (SCS), implemented with the aim to serve all student ability levels. Thus, this study's standard criteria requirements are fulfilled. In addition, data on the mathematical ability level were obtained from mathematics teachers by referring to the previous semester's scores. The first group comprised 12 students with moderate mathematical ability (6 male and 6 female), and the second consisted of 11 students with high mathematical ability (4 male and 7 female). Meanwhile, the third comprised 12 students with very high mathematical ability (6 male and 6 female), The participants' age range was 16-17 years, while the study duration was 6 months.

\section{Instruments and Materials}

The instruments and materials used in data collection and analysis include (1) CT skills test, which consists of 4 validated questions, (2) semi-structured interview, aimed to determine the students' CT skills in the moderate, high, and very high groups in solving mathematical problems related to the application of algebraic function derivatives, (3) digital voice recorder, in the form of a zoom application, which was used to record the interviews (Archibald et al., 2019). According to Bernard (2018), it is necessary to rely on both memory and field notes taken during the interview. (4) NVivo 12 plus software was used to enhance qualitative data analysis efficiency and facilitate the management of complex information (Feng \& Behar-Horenstein, 2019; Violetta Wilk, Geoffrey N. Soutar, 2019). However, it is unable to replace human processes (Bergeron \& Gaboury, 2020). (5) Ethical considerations, the permission to carry out this research was granted by universities, schools, mathematics teachers, participants, and their parents or guardians. Prior to the study, each participant signed a consent letter, and after the interview transcripts were completed, each participant read and confirmed the accuracy of the respective interview results. Also, participant initials were used to disguise the students' identity.

\section{Procedure}

This grounded theory research adopted a systematic procedure. A material centered on the application of algebraic function derivatives was distributed in class XI Senior High School to get closer to the participants to obtain more information from them. 
Furthermore, a Google Form application that consists of 4 questions was distributed to the 35 participants. In addition, their answers were traced and used to carry out in-depth interviews to determine their mathematical ability levels. Furthermore, in-depth interviews were carried out individually until the data reached the saturated category (Charmaz, 2014). This was reached after 15 interviews. It was started by asking some easy factual and personal questions, such as after school and students' daily activities and studying at home. The construct validity of the research findings was analyzed based on the basic principles and fundamental problems of critical thinking reviewed in existing literature (Ennis, 2015; Fisher, 2001; Halpern, 2014; McGregor, 2007). The questions for the interview were focused on the main subject, as illustrated in Table 1.

Table 1

The main interview questions on the application of algebraic function derivatives material

\begin{tabular}{|c|c|c|c|c|}
\hline & Question-1 & Question-2 & Question-3 & Question-4 \\
\hline & \multicolumn{4}{|l|}{ Theme-1: Reconstruction } \\
\hline 1 & $\begin{array}{l}\text { Problem-solving: based } \\
\text { on personal opinion, in } \\
\text { question number } 1 \text {, what } \\
\text { steps are needed to solve } \\
\text { the problem that have to } \\
\text { be stated? }\end{array}$ & $\begin{array}{l}\text { Argument: give } \\
\text { individual reasons, in } \\
\text { response to answer a, } \\
\text { whether the gradient of } \\
\text { the tangent to the } \\
f \text { curve always } \\
\text { negative or not. }\end{array}$ & $\begin{array}{l}\text { Interpretation of the } \\
\text { derivative: state the } \\
\text { conclusion regarding the } \\
\text { rising or falling of the graph } \\
\text { for the function } f \text { when } \\
x>0 \text { or } x<0 \text {. }\end{array}$ & $\begin{array}{l}\text { Strategy development: in } \\
\text { relation to personal } \\
\text { opinion, state the number } \\
\text { of ways (strategies) } \\
\text { required to answer the } \\
\text { questions above. }\end{array}$ \\
\hline & \multicolumn{4}{|c|}{ Theme-2: Relevance Identification } \\
\hline \multirow[t]{2}{*}{2} & $\begin{array}{l}\text { Reasoning: what } \\
\text { concepts (formulas) are } \\
\text { suitable for solving } \\
\text { problem number } 2 \text { for } \\
\text { parts a and b? (give your } \\
\text { opinion). }\end{array}$ & $\begin{array}{l}\text { Problem-solving: in } \\
\text { accordance with } \\
\text { personal opinion, state } \\
\text { the steps that need to } \\
\text { be taken first before } \\
\text { answering the } \\
\text { questions in sections a } \\
\text { and b. }\end{array}$ & $\begin{array}{l}\text { Analysis: based on the } \\
\text { reported answer, analyze the } \\
\text { graph of } y \text { curve along with } \\
\text { the equations of tangents. } \\
\text { (Note: slope; } \\
\text { up/down/horizontal). }\end{array}$ & $\begin{array}{l}\text { Argument: based on } \\
\text { question number } 2, \\
\text { explain the equation }\end{array}$ \\
\hline & \multicolumn{4}{|l|}{ Theme-3: Exploration } \\
\hline \multirow[t]{2}{*}{3} & $\begin{array}{l}\text { Problem-solving: } \\
\text { calculate the rate of } \\
\text { change of a balloon } \\
\text { volume with a radius of }\end{array}$ & $\begin{array}{l}\text { Strategy development: } \\
\text { based on personal } \\
\text { opinion, state the } \\
\text { number of ways to } \\
\text { solve question number } \\
\text { 3. Explain! }\end{array}$ & $\begin{array}{l}\text { Argument: according to } \\
\text { personal opinion, state the } \\
\text { meaning of rate of change } \\
\text { relating to the balloon's } \\
\text { volume reported in answer } \\
\text { a. }\end{array}$ & $\begin{array}{l}\text { Building definition: the } \\
\text { reason the first derivative } \\
\text { of a function is assumed } \\
\text { to be the rate of change. } \\
\text { Explain! }\end{array}$ \\
\hline & \multicolumn{4}{|l|}{ Theme-4: Classification } \\
\hline 4 & $\begin{array}{l}\text { Examining the } \\
\text { conceptual basis: in } \\
\text { accordance with } \\
\text { personal opinion, state } \\
\text { the concepts } \\
\text { (formulas/derivative } \\
\text { properties) used to } \\
\text { investigate the false } \\
\text { statements in questions } \\
1,2,3 \text {, and } 4 \text {. }\end{array}$ & $\begin{array}{l}\text { Evaluating: after } \\
\text { understanding the } \\
\text { basic concept } \\
\text { (formulas/derivative } \\
\text { properties), state or } \\
\text { evaluate the false } \\
\text { statements in questions } \\
1,2,3 \text {, and } 4 \text {. }\end{array}$ & & \\
\hline
\end{tabular}


In this study, interview bias was reduced to a minimum by permitting the expression of ideas. This led to the emergence of new questions and themes (Daugaard, 2020; F. Sadeghi, S. Adel, 2020). Furthermore, after recording the interviews, the results were transcribed and saved in word format to be analyzed in the NVivo 12 plus software. Subsequently, a follow-up session was carried out because several new questions were detected during each interview. However, these questions were considered (Corbin \& Strauss, 1990) and data analysis, which was carried out from the beginning because the results obtained also lead to subsequent interviews. Three levels of coding, namely open, axial and selective stages adopted from the systematic grounded theory proposed by Corbin \& Strauss (1990), were applied in this research, as shown in Figure 1.

First, data is analytically broken down into chunks and conceptual categories assigned to segments in the open coding stage. Additionally, approximately 782 codes were extracted from the data, with 171, 248, and 363 in moderate, high, and very high categories. Second, in the axial coding stage, the relationships between categories were discovered, combined, and grouped into core categories/central phenomena (Corbin \& Strauss, 1990).

Conversely, approximately 74 sub-categories and 9 categories were developed in selective coding. Finally, hypothetical conclusions obtained from the two previous stages were developed in selective coding. The 9 categories developed at the axial coding level were divided into 4 main themes: reconstruction, relevance identification, exploration, and classification, reflecting the level of skills for analytical thought. Subsequently, after building the theoretical model, in order to repeat the coding of the remaining samples according to the systematic grounding principle, a saturation test is carried out. Although supposing no new categories were found in the information extracted from the interview, it is assumed that the data is saturated, and the theory obtained is precise (the exam was passed by the). This means that the data has reached its saturation, thereby drawing hypothetical conclusions.

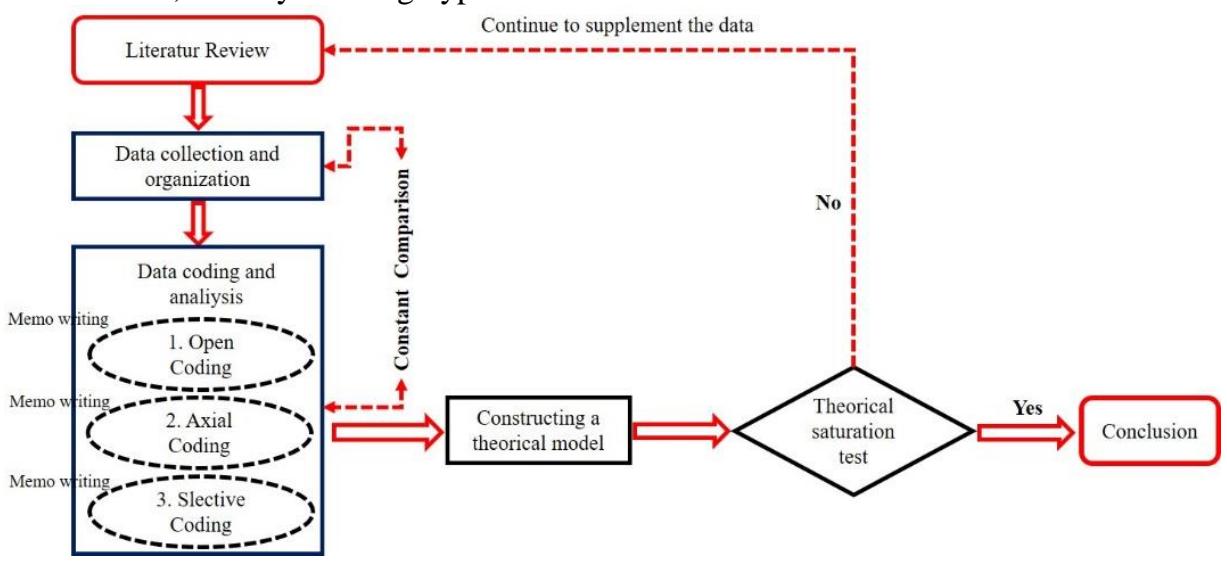

Figure 1

Grounded theory research procedures 


\section{Data Analysis}

The recordings were transcribed from the interviews, translated, and saved in word format before entered into the NVivo 12 plus software. Bias was avoided based on coding separately carried out in 2 studies aliens to the project (MI and SP). The kappa coefficient is a powerful statistical method to quantify the degree of agreement between qualitative or categorical item coders, such as themes and sub-themes found in interviews (Ghant et al., 2016). Additionally, when Cohen's kappa reliability value is 0.65 , the coding is reliable, and supposing its < 0.65, it is unreliable (McHugh, 2012; Penafiel et al., 2016; Warner et al., 2014).

Based on the results from the calculation, Cohen's kappa coefficient value obtained was 0.81. This means that the themes, categories, and sub-categories in this study are reliable. In the open coding, each interview's contents are read with the sentences highlighted, while the relevant code stated in the "Code System" is extracted. Figure 2 shows the main menu of NVivo 12 plus software used to search for sub-categories adopted in this study.

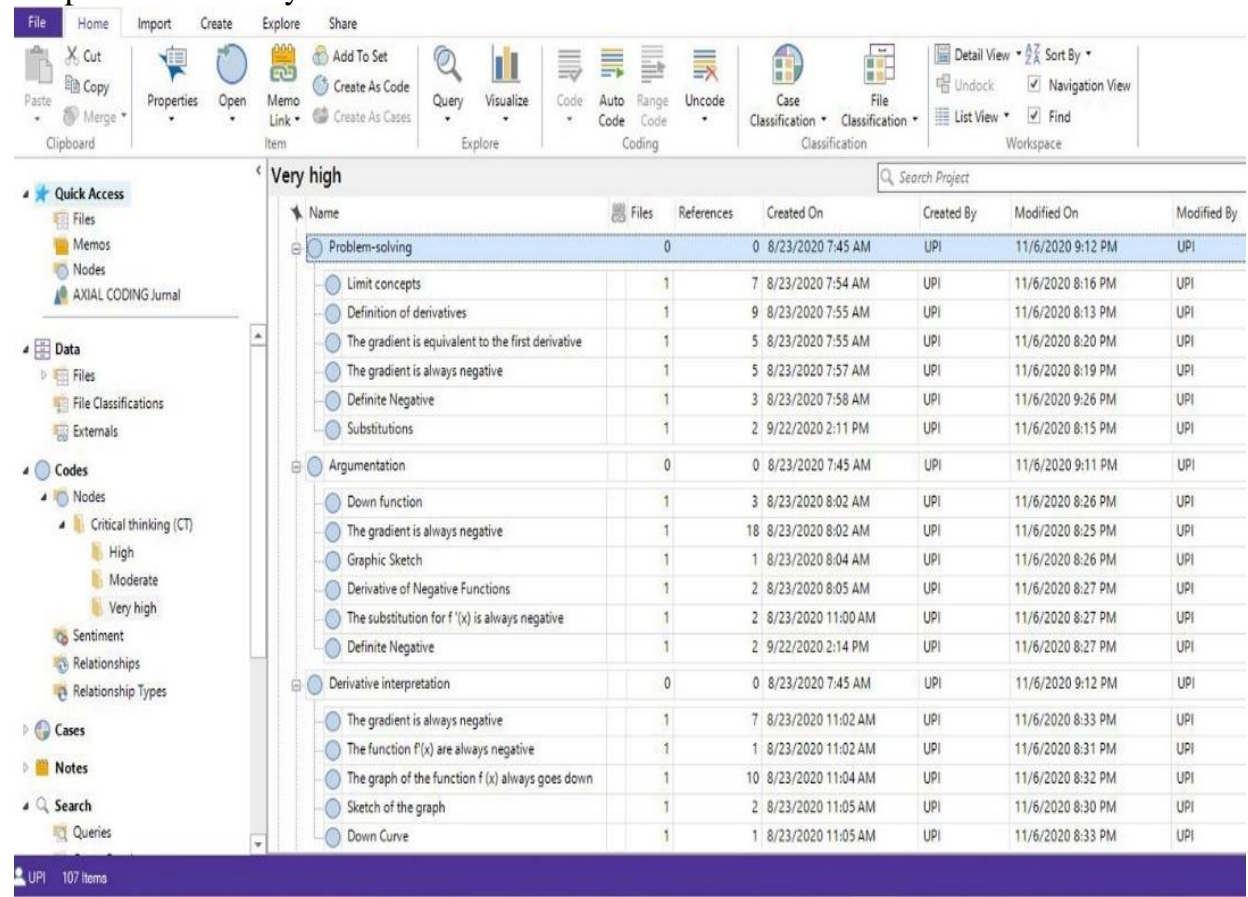

Figure 2

Codes and sub-codes in NVivo 12 plus software

Furthermore, in axial coding, the relationship between these codes was discovered and grouped into 74 sub-categories and 9 categories. Lastly, the selective coding encompasses four main categories developed as central phenomena regarding critical 
thinkers' characteristics, namely reconstruction, relevance identification, exploration, and classification. All of these are reflected in the core categories of this study, and it includes the students' critical thinking skills based on their mathematical ability levels (very high, high, and moderate), as shown in Table 1. A central aspect of grounded theory in accordance with system these're is the writing of memos (Corbin \& Strauss, 1990), which was taken into consideration from the inception of this research. This memo provides a solid basis for the reported research findings (Huon et al., 2019).

\section{FINDINGS}

Open, axial, and selective coding are the phases of this process. However, theoretical saturation was tested immediately after receiving the conceptual model, and the final model produced was analyzed.

\section{Open Coding}

In this stage, a code was attached to each student's answer on CT skills test results, google forms, and transcript of interviews in zoom based on their ideas in solving problems on the application of algebraic function derivatives. In this stage, 74 subcategories, 9 categories, and four main themes were generated as the central phenomena according to the characteristics of $\mathrm{CT}$ skills, such as reconstruction, relevance identification, exploration, and the classification of 35 participants. The following is the process of explaining each level of students' mathematical abilities.

\section{Moderate group student's critical thinking skills}

At the moderate mathematical ability level, 171 codes, 36 sub-categories, and 9 categories were realized in solving problems about the application of algebraic function derivatives. The sub-categories and categories that are evident in this group are shown in Table 2.

Table 2

Sub-categories and categories of students in the moderate group

\begin{tabular}{ll}
\hline Sub-categories & Categories \\
\hline $\begin{array}{l}\text { Definition of derivatives, substitutions, graphic sketches, limit concepts, tangent } \\
\text { equations, determining the volume of a sphere, the gradient is always negative, the } \\
\text { intersection of x and y axes, the gradient is equivalent to the first derivative, } \\
\text { ordinate, and abscissa, up and down functions. }\end{array}$ & Problem-solving \\
\hline $\begin{array}{l}\text { The gradient is a derivative of a negative function, tangent, positive and negative } \\
\text { gradients, up and down functions, and the relation of radius to the balloon volume, } \\
\text { which is equivalent to the first derivative. }\end{array}$ & Argumentation \\
\hline & \\
\hline & $\begin{array}{l}\text { Derivative } \\
\text { The graph of the function } f(x) \text { and the curve is always down. }\end{array}$ \\
\hline Definition of derivative and limit concept & $\begin{array}{l}\text { Strategy } \\
\text { development }\end{array}$ \\
\hline Quadratic function and limit concept, tangent equation formula, graphic sketch & Reasoning \\
\hline Positive and negative tangent gradients, down (left), and up functions (right). & Analyzing \\
\hline Rate of change in the interpretation of the first derivative & Building definition \\
\hline First, second, third and operational derivative concepts. & $\begin{array}{l}\text { Examining the } \\
\text { conceptual basis }\end{array}$ \\
\hline Substitution, definition of derivative, calculation, operational. & Evaluation \\
\hline
\end{tabular}


Based on the explanation, there are 11 sub-categories in problem-solving, 7 in argumentation, 2 in derivative interpretation, 2 in strategy development, 4 in reasoning, 3 in analyzing, 1 in building definition, 2 in examining the conceptual basis, and 4 subcategories in evaluation.

\section{High group students' critical thinking skills}

In accordance with the high level of mathematical ability, 248 codes, 54 sub-categories, and 9 categories were realized in solving problems in materials concerning the application of algebraic function derivatives, as shown in Table 3.

Table 3

Sub-categories and categories of students in high group

\begin{tabular}{ll}
\hline Sub-categories & Categories \\
\hline $\begin{array}{l}\text { Definition of derivatives, substitutions, graphic sketches, limit concepts, tangent } \\
\text { equations, determining the volume of a sphere, the gradient is always negative, } \\
\text { the intersection of x and y axes, gradient is equivalent to the first derivative, } \\
\text { ordinate and abscissa, up and down functions, and mathematical model. }\end{array}$ \\
\hline $\begin{array}{l}\text { The gradient is a derivative of a negative function, and tangent, up and down } \\
\text { functions, positive and negative gradients, the relationship between the radius of } \\
\text { a balloon and its volume, which is equivalent to the first derivative, the }\end{array}$ & Argumentation \\
& \\
substitution $f^{\prime}(x)$ is always negative, the volume of the balloon is equivalent to \\
the surface area of a ball.
\end{tabular}




\section{Very high group students' critical thinking skills}

This group encompasses 363 codes, 74 sub-categories, and 9 categories in solving mathematical problems in material concerning the application of algebraic function derivatives, and these are shown in Table 4.

\section{Table 4}

Sub-categories and categories of students in a very high group

\begin{tabular}{|c|c|}
\hline Sub-categories & Categories \\
\hline $\begin{array}{l}\text { Definition of derivative, substitution, graphic sketch, limit concept, tangent } \\
\text { equation, determining the volume of a ball, the gradient is always negative, the } \\
\text { intersection of } x \text { and y axes, gradient is equivalent to the first derivative, ordinate } \\
\text { and abscissa, up and down functions, mathematical model, conclusion, negative } \\
\text { definite, maximum and minimum values. }\end{array}$ & Problem-solving \\
\hline $\begin{array}{l}\text { The gradient and derivative function are always negative, the gradient of a tangent, } \\
\text { up and down functions, positive and negative gradients, the relationship between } \\
\text { the radius and volume of the balloon volume, which is equivalent to the first }\end{array}$ & Argumentation \\
\hline \multicolumn{2}{|l|}{$\begin{array}{l}\text { derivative, the substitution } f^{\prime}(x) \text { is always negative, the volume of the balloon is } \\
\text { equivalent to the surface area of a ball, definite negative, graph sketches, and } \\
\text { gradients intersecting the } \mathrm{x} \text { and y axes }\end{array}$} \\
\hline \multirow{2}{*}{\multicolumn{2}{|c|}{ The graph of the function $f(x)$ and the curve are always down, the gradient and }} \\
\hline & \\
\hline $\begin{array}{l}\text { Definition of derivative and limit concepts, multiple point test, derivative } \\
\text { properties, graph method, the rate of change of the balloon is equivalent to the } \\
\text { surface area of a ball, analysis of the function form, and mathematical induction }\end{array}$ & $\begin{array}{l}\text { Strategy } \\
\text { development }\end{array}$ \\
\hline $\begin{array}{l}\text { The concept of a quadratic function, tangent equation formula, graph sketch, limit } \\
\text { concept, gradient equivalent to the first derivative, the definition of the derivative, } \\
\text { the intersection points of } \mathrm{x} \text { and } \mathrm{y} \text { axes, stationary, and relative maximum turning } \\
\text { points. }\end{array}$ & Reasoning \\
\hline $\begin{array}{l}\text { Gradients of positive and negative tangents, down (left), up functions (right), } \\
\text { relative minimum turning, stationary points, minimum tangent gradient, and } \\
\text { negative and positive definite. }\end{array}$ & Analyzing \\
\hline $\begin{array}{l}\text { The rate of change in the interpretation of the first derivative, gradient instantaneous } \\
\text { and average rate of change, as well as the limit concept }\end{array}$ & Building definition \\
\hline $\begin{array}{l}\text { First, second, third, and operational derivative concepts, checking for continuity of } \\
\text { limits, substitution, and conclusion }\end{array}$ & $\begin{array}{l}\text { Examining the } \\
\text { conceptual basis }\end{array}$ \\
\hline $\begin{array}{l}\text { Substitution, the definition of derivatives, calculation, operational, searching for } \\
\text { false statements, identifying equation, and limiting concepts. }\end{array}$ & Evaluation \\
\hline
\end{tabular}

Based on this analysis, there are 15 sub-categories in problem-solving, 13 in argumentation, 5 in derivative interpretation, 8 in strategy development, 9 in reasoning, 7 in analyzing, 6 in building definition, 4 examining the conceptual basis, and 7 subcategories in evaluation.

In accordance with the explanation, it is obvious that the higher the degree of mathematical skill in the sub-categories, the greater the number of participants. In the problem-solving categories shown in Tables 2, 3, and 4, the students in the middle group were able to resolve issues relating to the concept of down and up functions, while those 
in the high group were able to solve problems relating to the mathematical model. Subsequently, the very high group participants were able to resolve the concluding aspect, coupled with definite negative analysis, including the maximum and minimum values, as shown in Figure 3 below.

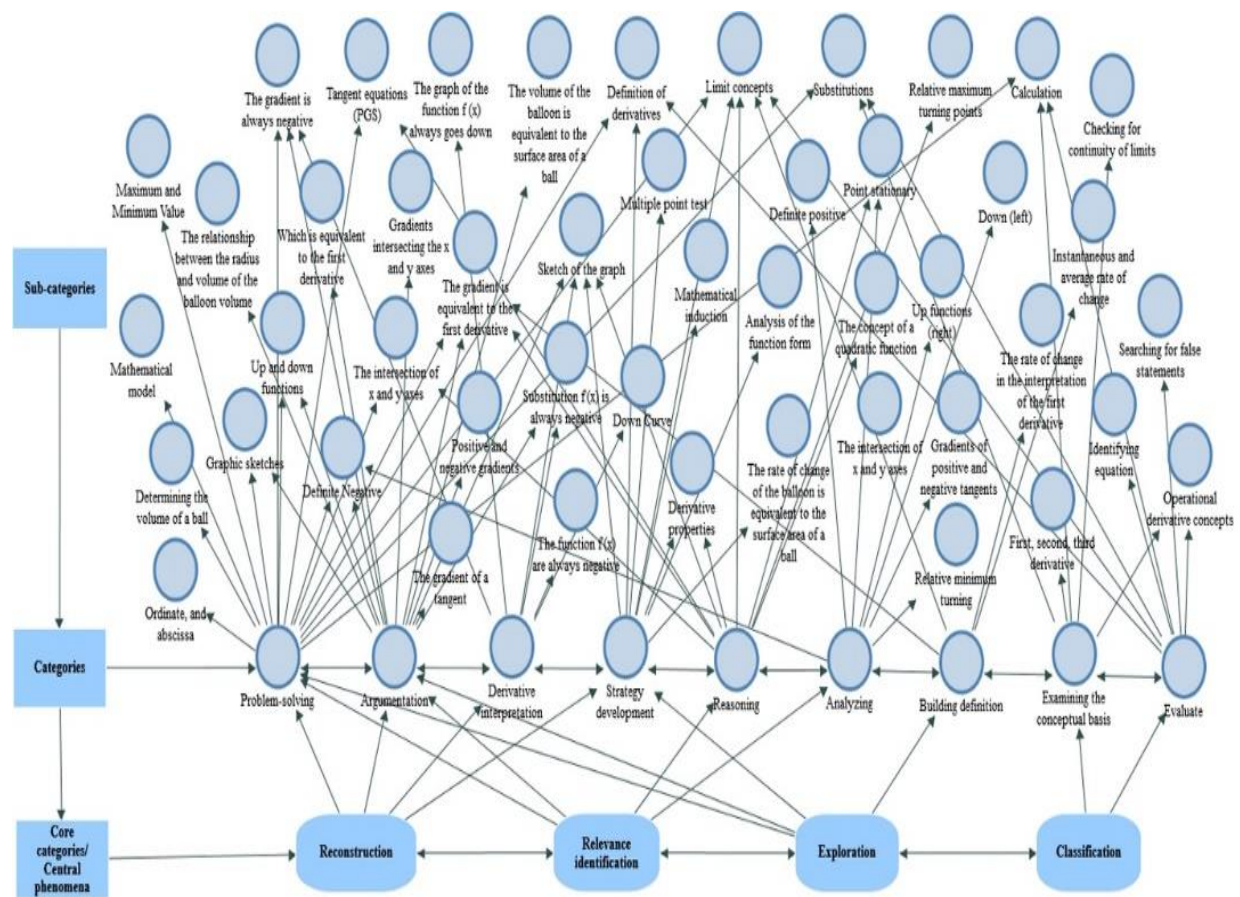

Figure 3

Diagram of the open coding process

Based on the open coding results, four core categories support students' critical thinking (CT) ability in materials concerning the application of algebraic function derivatives, namely reconstruction, relevance identification, exploration, and classification. Students that possess the reconstruction skills are able to solve problems, interpret derivatives, develop strategies, and arguments. Furthermore, those that possess relevance identification are able to solve problems, establish arguments, reason, and analyze. Those of them that possess exploration skills are able to solve problems, develop strategies, establish arguments, and offer meanings that appear as a function of the derivative. Meanwhile, students that possess classification skills tend to examine the basic concepts and evaluate the functions of a derivative. Therefore, the higher the students' mathematical ability level, the higher the various sub-categories discovered in the derivative concept, as shown in Figure 3. Although immediately the open coding process and core categories are discovered, the next stage is the axial coding process. 


\section{Axial Coding}

In this stage, one category of open coding is placed at the center of the studied process. It is referred to as the core phenomenon, which causally relates to the other categories, as shown in Figure 4.

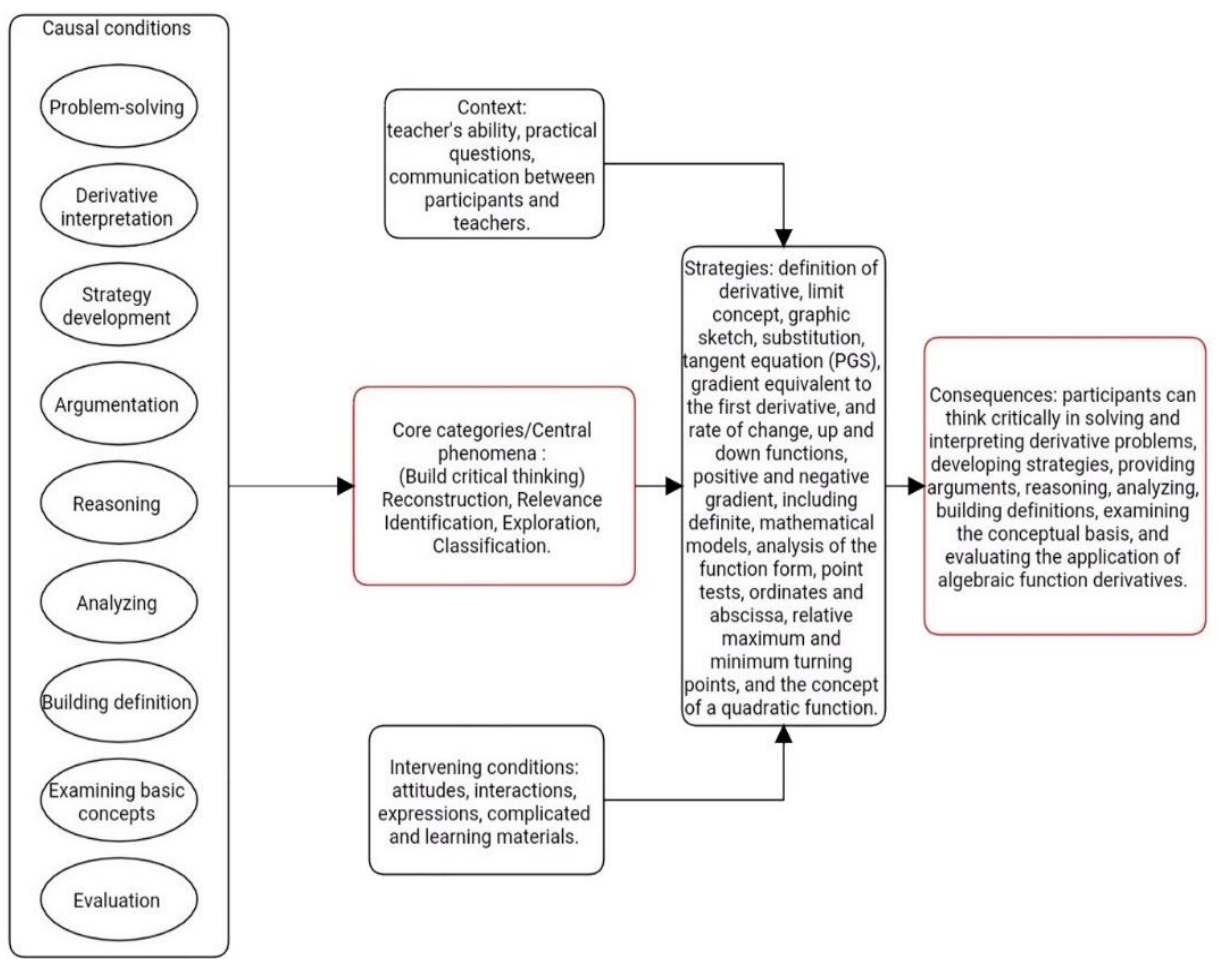

Figure 4

Axial coding process

Derived from the paradigm in Figure 4, there are six boxes (categories) of information obtained from this study. (1) These causal conditions affect the core categories, namely problem-solving, derivative interpretation, strategy development, argumentation, reasoning, analyze, building definitions, examining the conceptual basis, and evaluation. These causal categories influence the core/central phenomena critical thinking (CT) ability. (2) The core category/central phenomenon is CT skills (reconstruction, relevance identification, exploration, and classification), (3) Strategy is a special action that arises from the core phenomenon, it includes the definition of derivative, limit concept, graphic sketch, substitution, tangent equation (PGS), gradient equivalent to the first derivative, and rate of change, up and down functions, positive and negative gradient, including definite, mathematical models, analysis of the function form, point tests, ordinates and abscissa, relative maximum and minimum turning points, and the concept of a quadratic function. All these strategies emerged in critical thinking (CT) on 
the derivative material. (4) Context is a special condition that affects strategy. In this study, it was discovered that (a) the capacity of the teacher to master the method and materials of learning, (b) the practical questions are given to students stimulate their critical thinking processes, and (c) the communication between participants and teachers is the inception of the development of their' critical thinking skills. (5) Intervention conditions that affect the strategies in this research include (a) students' attitudes when responding to a given problem, (b) interactions that occur in the class, (c) the funny students' facial expressions when they are able to solve a given question, (d) complicated implies that students are able to establish perfect arguments, and (e) master the learning materials thereby being able to solve these problems. (6) Consequences occur due to these strategies. In this research, participants can think critically in solving and interpreting derivative problems, developing strategies, providing arguments, reasoning, analyzing, building definitions, examining the conceptual basis, and evaluating the application of algebraic function derivatives.

\section{Selective Coding}

In this stage, a theory that is interrelated to the categories in the axial coding model and traces personal memos about participants' ideas discovered in the field was proposed. The selective coding process is shown in Figure 5.

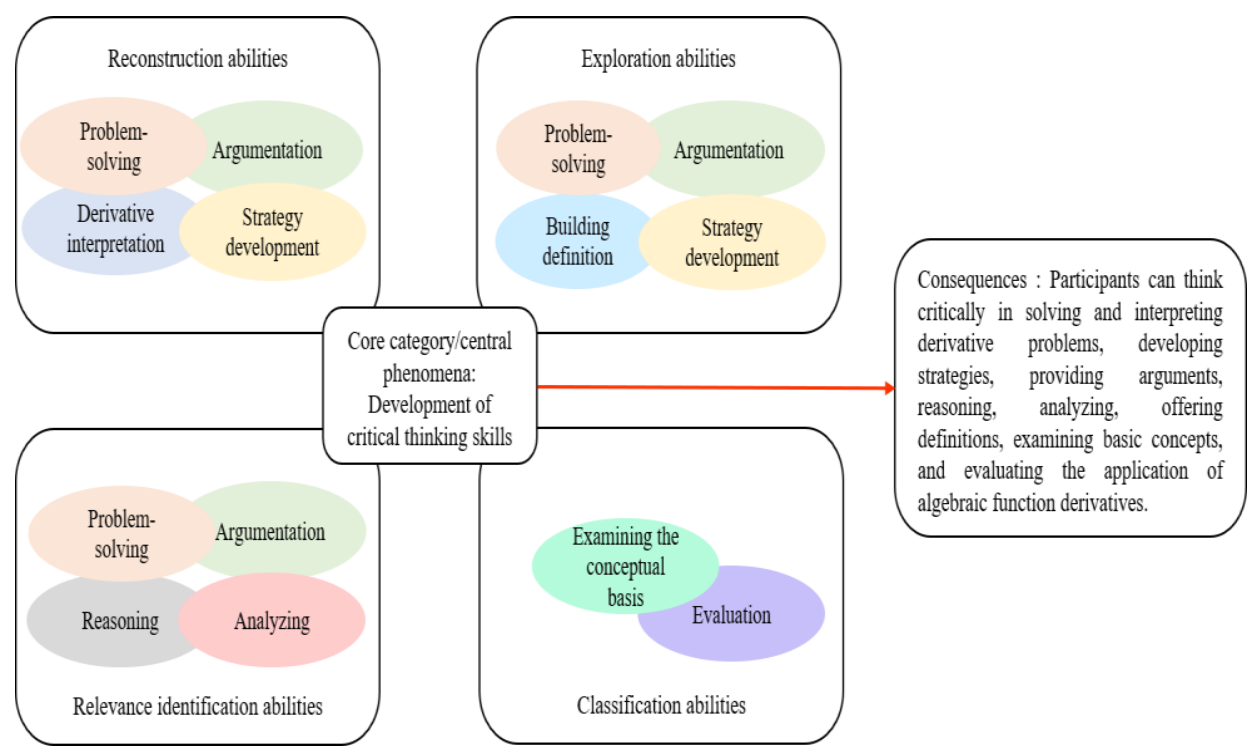

Figure 5

Selective coding process

Hypothetical conclusions explaining the relationship between the categories in the selective coding paradigm was produced in this stage. However, this was realized after a saturation test based on the interview data was carried out using NVivo 12 plus software. 


\section{Saturation Test}

The rationale behind the theoretical saturation test is to repeat the coding of the remaining samples in the systematic grounded theory according to the steps. Consequently, when the information extracted from the interview data is saturated, and a reliable theory is obtained, it implies that the test was successful ( $\mathrm{Li}, 2019)$. After carrying out the theoretical saturation test, no new categories were discovered asides from the nine (problem-solving, derivative interpretation, strategy development, argumentation, reasoning, analysis, building definitions, examining the conceptual basis, and evaluation) and four core categories that lead to the development of critical thinking (CT) skills (reconstruction, relevance identification, exploration, and classification), therefore the data was saturated.

\section{The Structure of the Analysis}

In accordance with the method of open, axial, and selective coding, as well as theoretical saturation tests, it was verified that saturated theoretical models were the critical thinking abilities of the students and their level of mathematical ability to complete the derivative materials and applications produced in this study. According to this model, a general hypothetical conclusion was obtained "when the students' critical thinking skills are enhanced, their patterns of solving problems relating to the application of algebraic function derivatives are increasingly diverse." The typical hypothetical conclusions in Figure 5 are illustrated as follows:

\section{Hypothetical conclusion 1.}

"If the participants possess reconstruction ability, they are presumed to have critical thinking skills."

The reconstruction abilities obtained include problem-solving, derivative interpretation, argumentation, and strategy development. Therefore, participants possess critical thinking skills in solving problems relating to the application of algebraic derivatives functions.

\section{Hypothetical conclusion 2.}

"If the participants have relevance identification ability, they are presumed to possess critical thinking skills."

The relevance identification abilities realized are problem-solving, reasoning, argumentation, and analyzing. Therefore, the participants possess critical thinking skills in solving problems based on the application of algebraic derivative functions.

\section{Hypothetical conclusion 3.}

"If the participants possess exploration ability, they are reported to have critical thinking skills."

The exploration abilities obtained are problem-solving, developing strategies, arguments, and definitions of the function derivatives' symbols. Therefore, in line with 
the implementation of algebraic derivative functions, they possess logical reasoning abilities in solving problems.

\section{Hypothetical conclusion 4.}

Subsequently, when "the participants possess classification ability, they are assumed to have critical thinking skills."

The classification abilities developed include being able to examine and evaluate the basic concepts and derivative functions. Therefore, participants possess critical thinking skills in solving problems relating to the application of algebraic derivative functions.

\section{DISCUSSION}

The Critical Thinking Ability of Students in Moderate, High and Very High groups in Solving Mathematical Problems within the Application of Algebra Function Derivatives Material.

Based on the mathematical CT ability in solving problems within the application of algebraic function derivatives, four themes, reconstruction ability, relevance identification ability, exploration ability, and classification ability, were discovered. The four themes were interrelated with the nine categories building this study's central phenomenon, the students' CT ability based on the mathematical ability level. These categories include problem solving, argumentation, derivative interpretation, strategy development, reasoning, analysis, building definitions, conceptual basis examination, and evaluation aspects.

In the moderate group students, the least categories discovered were building definitions, derivative interpretation, strategy development, and conceptual basis examination. At the time, numerous participants experienced errors in applying algebraic function derivatives material, and most participants made procedural as well as conceptual errors (Fisher, 2001). Procedural errors are corrected with certain types of tasks, however, basic conceptual misconceptions tend to be more difficult to correct, depending on personality (Fisher, 2001). Meanwhile, mathematical misunderstandings are corrected by a deep learning process (Clements \& Sarama, 2020; Sztajn et al., 2012).

The high group students were more careful in problem solving, and this is evident in the participant categories discovered. In terms of diction, all high mathematical ability participants attempted to use more profound language, and this was evident in the use of higher vocabulary, compared to participants with moderate mathematical ability levels. Furthermore, the strategy development of solution utilized by high group students was the most important factor to strengthen critical thinking, in viewing problems from various perspectives (F. Sadeghi, S. Adel, 2020; Miller \& Topple, 2020; Moon, 2007).

Meanwhile, students in the very high group exhibited greater control over problems. This is evident in the categories of argumentation and reasoning appearing with highly significant changes in the problem-solving process. In this group, a more varied completion strategy was used, and the concept basis examination process was deeper, 
compared to the other two skill levels (moderate and high). The two most dominant aspects at in this group are argumentation and reasoning. This is in line with the results of several previous studies (F. Sadeghi, S. Adel, 2020; Facione, 1990; Halpern, 1998; McGregor, 2007), emphasizing a critical thinker's most important characteristics, argumentation and reasoning, where argumentation is described as cognitive activity, and reasoning is the key to developing critical thinking. Several previous studies have supported the CT theory, including (F. Sadeghi, S. Adel, 2020), stating the variety of student mindsets is highly dependent on the students' intellectual capacity in problemsolving. Therefore, developing a variety of student mindsets ought to be started from a learning process with the capacity to stir students' minds. This is in line with these findings, a higher mathematical CT ability, implies a more diverse thinking patterns in solving problems of algebraic functions derivative application.

\section{CONCLUSION}

The research findings are expected to help educational practitioners develop students' CT abilities in learning, by paying attention to aspects of the researcher's findings in critical thinking, including reconstruction ability, identification of relevance, exploration and classification. In addition, students with moderate mathematical ability in CT experience difficulties and mistakes in solving problems, while the high group counterparts exhibited critical thinking ability to be more careful in solving problems. Each argument, analysis, reasoning, and strategy used is evaluated by examining the basic concepts used. Meanwhile, the very high group showed CT abilities vary widely in problem solving and were able to provide solutions to anyone solving similar problems. Based on the explanation above, higher mathematical abilities lead to a more diverse thinking pattern in students. This shows higher mathematical abilities makes developing students' CT abilities easier for teachers.

The findings from this research are limited to students with moderate, high, and very high mathematical abilities; therefore, those with low mathematical abilities lack critical thinking skills. Therefore, due to the importance of exploring these skills, further studies need to be carried out on students with low mathematical abilities.

\section{ACKNOWLEDGMENTS}

The authors are grateful to Senior High School 3 Bandung for allowing the conduction of this, NVivo Indonesia Training Center, scholarship program of 5000 doctors for sponsoring this research, as well as M. Ikhsan and Sufyani Prabawanto as coders outside the research project.

\section{REFERENCES}

Archibald, M. M., Ambagtsheer, R. C., Casey, M. G., \& Lawless, M. (2019). Using Zoom Videoconferencing for Qualitative Data Collection: Perceptions and Experiences of Researchers and Participants. International Journal of Qualitative Methods, 18, 1-8. https://doi.org/10.1177/1609406919874596 
As'ari, A. R., Kurniati, D., \& Subanji. (2019). Teachers expectation of students' thinking processes in written works: A survey of teachers' readiness in making thinking visible. Journal on Mathematics Education, 10(3), 409-424. https://doi.org/10.22342/jme.10.3.7978.409-424

Association of American Colleges and Universities. (2005). Liberal education outcomes: A preliminary report on student achievement in college. AAC\&U. https://www.aacu.org/sites/default/files/files/LEAP/LEAP_Report_2005.pdf

Australian Council for Educational Research. (2002). Graduate skills assessment: Stage one validity study. Department of Education, Science and Training. https://research.acer.edu.au/higher_education/27

Basri, H., Purwanto, As'ari, A. R., \& Sisworo. (2019). Investigating critical thinking skill of junior high school in solving mathematical problem. International Journal of Instruction, 12(3), 745-758. https://doi.org/10.29333/iji.2019.12345a

Bergeron, D. A., \& Gaboury, I. (2020). Challenges related to the analytical process in realist evaluation and latest developments on the use of NVivo from a realist perspective. International Journal of Social Research Methodology, 23(3), 355-365. https://doi.org/10.1080/13645579.2019.1697167

Bernard, H. R. (2018). Research methods in anthropology: Qualitative and quantitative approaches (6th ed). Rowman \& Littlefield Publishers.

Changwong, K., Sukkamart, A., \& Sisan, B. (2018). Critical thinking skill development: Analysis of a new learning management model for Thai high schools. Journal of International Studies, 11(2), 37-48. https://doi.org/10.14254/2071-8330.2018/11-2/3

Charmaz, K. (2014). Constructing Grounded Theory. 2nd ed. Sage Publications.

Clements, D. H., \& Sarama, J. (2020). Learning and Teaching Early Math. Learning and Teaching Early Math. https://doi.org/10.4324/9781003083528

Corbin, J. M., \& Strauss, A. (1990). Grounded theory research: Procedures, canons, and evaluative criteria. Qualitative Sociology, 13(1), 3-21. https://doi.org/10.1007/BF00988593

Creswell, J. W. (2012). Educational research: Planning, conducting, and evaluating quantitative and qualitative research fourth edition. Pearson., inc.

Darhim, Prabawanto, S., \& Susilo, B. E. (2020). The effect of problem-based learning and mathematical problem posing in improving student's critical thinking skills. International Journal of Instruction, 13(4), 103-116. https://doi.org/10.29333/iji.2020.1347a 
Daugaard, D. (2020). Emerging new themes in environmental, social and governance investing: a systematic literature review. Accounting and Finance, 60(2), 1501-1530. https://doi.org/10.1111/acfi.12479

Dwyer, C. P., Hogan, M. J., \& Stewart, I. (2012). An evaluation of argument mapping as a method of enhancing critical thinking performance in e-learning environments. Metacognition and Learning, 7(3), 219-244. https://doi.org/10.1007/s11409-012-9092-1

Ennis, R. H. (1993). Critical thinking assessment. Theory Into Practice, 32(3), 179-186. https://doi.org/10.1080/00405849309543594

Ennis, R. H. (2015). Critical Thinking: A Streamlined Conception. The Palgrave Handbook of Critical Thinking in Higher Education, 31-47. https://doi.org/10.1057/9781137378057_2

F. Sadeghi, S. Adel, G. Z. \& M. D. (2020). Iranian EFL teachers' and learners' perceptions of the principles of critical thinking: A constructivist grounded theory study. Iranian Journal of Language Teaching Research, 8(2), 63-81. https://www.scopus.com/inward/record.uri?partnerID=HzOxMe3b\&scp=85087881655 \&origin=inward

Facione. (1990). Critical Thinking: A Statement of Expert Consensus for Purposes of Educational Assessment and Instruction. Research Findings and Recommendations. The California Academic Press.

Facione, P. A. (1992). Critical thinking: What it is and why it counts. In Insight assessment. The California Academic Press.

Feng, X., \& Behar-Horenstein, L. (2019). Maximizing NVivo utilities to analyze openended responses. Qualitative Report, 24(3), 563-571. https://nsuworks.nova.edu/tqr/vol24/iss3/11

Fisher, A. (2001). An Introduction to Critical Thinking. Cambridge.

Ghant, M. S., Sengoba, K. S., Vogelzang, R., Lawson, A. K., \& Marsh, E. E. (2016). An Altered Perception of Normal: Understanding Causes for Treatment Delay in Women with Symptomatic Uterine Fibroids. Journal of Women's Health, 25(8), 846-852. https://doi.org/10.1089/jwh.2015.5531

Glaser, B. G., \& Strauss, A. (1967). The discovery of grounded theory: Strategies for qualitative research. Canada: Transaction.

Hage, G. (2020). The haunting figure of the useless academic: Critical thinking in coronavirus time. European Journal of Cultural Studies, 23(4), 662-666. https://doi.org/10.1177/1367549420926182

Halpern. (1998). Teaching critical thinking for transfer across domains. American Psychologist, 53(4), 449-455. https://doi.org/10.1037//0003-066x.53.4.449 
Halpern, D. F. (2014). Thought and Knowledge : An Introduction to Critical Thinking. In Educational Psychology in Practice (Fifth Edit, Vol. 30, Issue 4). Taylor \& Francis Group. https://doi.org/10.1080/02667363.2014.934516

Huon, J. F., Roux, C., Pourrat, X., Conort, O., Ferrera, F., Janoly-Dumenil, A., Lehmann, A., Ruspini, E., Allenet, B., \& Honoré, S. (2019). Memo form: Pharmaceutical interviews. Pharmacien Hospitalier et Clinicien, 54(4), 417-423. https://doi.org/10.1016/j.phclin.2019.09.004

Ismajli, H., \& Neziri, M. (2019). Analyzing languages and communication textbooks in the context of achieving competence: Student as a critical thinker. International Journal of Instruction, 12(4), 251-266. https://doi.org/10.29333/iji.2019.12416a

Karpouza, E., \& Emvalotis, A. (2019). Exploring the teacher-student relationship in graduate education: a constructivist grounded theory. Teaching in Higher Education, 24(2), 121-140. https://doi.org/10.1080/13562517.2018.1468319

$\mathrm{Li}, \mathrm{X}$. (2019). Green development behavior and performance of industrial enterprises based on grounded theory study: Evidence from China. Sustainability, 11(15), 4133. https://doi.org/10.3390/su11154133

Lin, S., Hu, H.-C., \& Chiu, C.-K. (2019). Training Practices of Self-efficacy on Critical Thinking Skills and Literacy: Importance-Performance Matrix Analysis. EURASIA Journal of Mathematics, Science and Technology Education, 16(1), 1-10. https://doi.org/10.29333/ejmste/112202

Marzuki, Asih, E. C. M., \& Wahyudin. (2019). Creative thinking ability based on learning styles reviewed from mathematical communication skills. Journal of Physics: Conference Series, 1315(1). https://doi.org/10.1088/1742-6596/1315/1/012066

McGregor, D. (2007). Developing thinking; developing learning : a guide to thinking skills in education. Open University Press. http://vct.qums.ac.ir/portal/file/?180494/Developing-thinking_-developing-learning.pdf

McHugh, M. L. (2012). Lessons in biostatistics interrater reliability: the kappa statistic. Biochemica Medica, 22(3), 276-282. https://doi.org/10.11613 / BM.2012.031

Menteri Pendidikan dan Kebudayaan Republik Indonesia. (2016). Peraturan Menteri Pendidikan dan Kebudayaan Pemerintah Indonesia Nomor 21 Tahun 2016 Tentang Standar Isi Pendidikan Dasar dan Menengah. 6 June 2016. https://luk.staff.ugm.ac.id/atur/bsnp/Permendikbud21-2016SIDikdasmen.pdf

Miller, S. E., \& Topple, T. A. (2020). Thinking and Thinking About Thinking: A Qualitative Study of Learning in a Process-Centric Teaching Model. Journal of Social Work Education, 56(1), 115-130. https://doi.org/10.1080/10437797.2019.1648224 
Moon, J. (2007). Critical thinking: An exploration of theory and practice. In Critical Thinking: An Exploration of Theory and Practice. https://doi.org/10.4324/9780203944882

Osman, S., Abu, M. S., Mohammad, S., \& Mokhtar, M. (2016). Identifying pertinent elements of critical thinking and mathematical thinking used in civil engineering practice in relation to engineering education. Qualitative Report, 21(2), 212-227. https://nsuworks.nova.edu/tqr/vol21/ iss $2 / 4$

Penafiel, D., Termote, C., Lachat, C., Espinel, R., Kolsteren, P., \& Van Damme, P. (2016). Barriers to Eating Traditional Foods Vary by Age Group in Ecuador With Biodiversity Loss as a Key Issue. Journal of Nutrition Education and Behavior, 48(4), 258-268.e1. https://doi.org/10.1016/j.jneb.2015.12.003

Sarwanto, Fajari, L. E. W., \& Chumdari. (2020). Open-Ended Questions to Assess Critical-Thinking Skills in Indonesian Elementary School. International Journal of Instruction, 14(1), 615-630. https://doi.org/10.29333/IJI.2021.14137A

Setiyani, Putri, D. P., Ferdianto, F., \& Fauji, S. H. (2020). Designing a digital teaching module based on mathematical communication in relation and function. Journal on Mathematics Education, 11(2), 223-236. https://doi.org/10.22342/jme.11.2.7320.223236

Store, J. C. (2018). Grounded theory of productive practices for algebraic thinking. Investigations in Mathematics Learning, 10(1), 9-32. https://doi.org/10.1080/19477503.2017.1375353

Sustekova, E., Kubiatko, M., \& Usak, M. (2019). Validation of critical thinking test on Slovak conditions. Eurasia Journal of Mathematics, Science and Technology Education, 15(12). https://doi.org/10.29333/ejmste/112295

Sztajn, P., Confrey, J., Wilson, P. H., \& Edgington, C. (2012). Learning Trajectory Based Instruction: Toward a Theory of Teaching. Educational Researcher, 41(5), 147156. https://doi.org/10.3102/0013189X12442801

Tanudjaya, C. P., \& Doorman, M. (2020). Examining higher order thinking in Indonesian lower secondary mathematics classrooms. Journal on Mathematics Education, 11(2), 277-300. https://doi.org/10.22342/jme.11.2.11000.277-300

Violetta Wilk, Geoffrey N. Soutar, P. H. (2019). Tackling social media data analysis: Comparing and contrasting QSR NVivo and Leximancer. Qualitative Market Research, 22(2), 94-113. https://doi.org/10.1108 / QMR-01-2017-0021

Wang, Q., \& Woo, H. L. (2010). Investigating students' critical thinking in weblogs: An exploratory study in a Singapore secondary school. Asia Pacific Education Review, 11(4), 541-551. https://doi.org/10.1007/s12564-010-9101-5 
Warner, E. L., Montenegro, R. E., Stroup, A., Kinney, A. Y., \& Kirchhoff, A. C. (2014). Health care concerns of rural childhood cancer survivors. Journal of Health Care for the Poor and Underserved, 25(2), 901-912. https://doi.org/10.1353/hpu.2014.0095

Widyatiningtyas, R., Kusumah, Y. S., Sumarmo, U., \& Sabandar, J. (2015). The impact of problem-based learning approach tosenior high school students' mathematics critical thinking ability. Journal on Mathematics Education, 6(2), 30-38. https://doi.org/10.22342/jme.6.2.2165.107-116 